\title{
Editorial
}

\section{Top 5 Cited Papers in the Section of Biocatalysis}

\author{
Evangelos Topakas (1)
}

check for

updates

Citation: Topakas, E. Top 5 Cited Papers in the Section of Biocatalysis. Catalysts 2021, 11, 27. https:// doi.org/10.3390/catal11010027

\section{Received: 19 December 2020}

Accepted: 28 December 2020

Published: 29 December 2020

Publisher's Note: MDPI stays neutral with regard to jurisdictional claims in published maps and institutional affiliations.

Copyright: () 2020 by the author. Licensee MDPI, Basel, Switzerland. This article is an open access article distributed under the terms and conditions of the Creative Commons Attribution (CC BY) license (https: / / creativecommons.org/ licenses/by/4.0/).
Industrial Biotechnology and Biocatalysis Group, Biotechnology Laboratory, Zografou Campus, School of Chemical Engineering, National Technical University of Athens, 5 Iroon Polytechniou Str., 15780 Athens, Greece; vtopakas@chemeng.ntua.gr; Tel.: +30-210-772-3264

I have the honor of writing this editorial note on the top 5 cited papers published in 2018 in the section of Biocatalysis of the Catalyst journal. Most of the highly cited studies are reviews, mainly involving enzyme immobilization articles, including redox enzyme orientation on electrodes, while there are articles focused on the industrial application of enzymes and on the recent advances in $\omega$-transaminase-mediated biocatalysis.

The paper gathering the highest number of citations is the review article authored by Zdarta et al. [1], which provides a general overview of the characteristics and properties of the materials applied for enzyme immobilization. This paper will be useful in the selection of appropriate support materials, divided into two main groups called "Classic" and "New Materials," with tailored properties for the production of highly effective biocatalytic systems for use in various processes.

The second paper is a review article on the industrial applications of enzymes and their recent advances, techniques, and outlooks [2]. It is well accepted that enzymes, as industrial biocatalysts, offer numerous advantages over traditional chemical processes with respect to sustainability and process efficiency. This review article discusses how biocatalysis has been successfully deployed and how enzyme immobilization can improve industrial processes. It also focuses on the analysis tools critical for the multiscale implementation of enzyme immobilization for increased product yield at maximum market profitability and minimum logistical burden on the environment and user.

In third position of the most cited papers is again a review article dedicated to the recent advances in $\omega$-transaminase-mediated biocatalysis for the enantioselective synthesis of chiral amines [3]. Chiral amines are important components of $40-45 \%$ of small molecule pharmaceuticals and many other industrially important fine chemicals and agrochemicals. However, the industrial application of $\omega$-transaminases for the production of such compounds is limited by factors, such as disfavored reaction equilibrium, poor substrate scope, and product inhibition. In this article, a closer look was taken at the recent developments in overcoming these challenges by various reaction engineering approaches. Furthermore, protein engineering techniques, which play a crucial role in improving the substrate scope of these biocatalysts and their operational stability, are also presented. Finally, the incorporation of $\omega$-transaminases in multienzymatic cascades, which significantly improves their applicability in the synthesis of complex chemical compounds, is detailed.

The next study in the row is a research article on the immobilization and stabilization of ficin extract on glutaraldehyde-activated agarose beads [4]. In this work, the authors investigated the variables that control the final stability and activity in protein hydrolysis. It was shown that ficin extract was successfully immobilized at $\mathrm{pH} 7$, while the aminated support was unable to immobilize more than $30-40 \%$ of the enzyme. Stabilization depended on the $\mathrm{pH}$ and the substrate used to determine the residual activity, being larger when using benzoyl-arginine- $p$-nitroanilide (BANA) and shorter when using casein. Results suggest a complex net of interactions between enzyme and support that differently affect the activity versus the different substrates.

Last but not least, another review article that is highly cited is by Hitaishi et al., which deals with the controlling redox enzyme orientation at planar electrodes [5]. Redox 
enzymes, which catalyze reactions involving electron transfers in living organisms, are very promising components of biotechnological devices and can be envisioned for sensing applications in addition to energy conversion. In this context, one of the most significant challenges is to achieve efficient direct electron transfer by tunneling between enzymes and conductive surfaces. Based on various examples of bioelectrochemical studies described in the recent literature, this review article discusses the issue of enzyme immobilization at planar electrode interfaces. The analytical techniques that have enabled the characterization and quantification of the successful achievement of the desired orientation are also discussed in this investigation.

Through my role as editor-in-chief in the section of Biocatalysis, I would like to express my gratitude to all the authors for their valuable contributions, which resulted in high readability and citation frequency of their published works, as well as to the editorial team of the Catalysts journal for their support.

\section{References}

1. Zdarta, J.; Meyer, A.S.; Jesionowski, T.; Pinelo, M. A General Overview of Support Materials for Enzyme Immobilization: Characteristics, Properties, Practical Utility. Catalysts 2018, 8, 92. [CrossRef]

2. Chapman, J.; Ismail, A.E.; Dinu, C.Z. Industrial Applications of Enzymes: Recent Advances, Techniques, and Outlooks. Catalysts 2018, 8, 238. [CrossRef]

3. Patil, M.D.; Grogan, G.; Bommarius, A.; Yun, H. Recent Advances in $\omega$-Transaminase-Mediated Biocatalysis for the Enantioselective Synthesis of Chiral Amines. Catalysts 2018, 8, 254. [CrossRef]

4. Siar, E.-H.; Arana-Peña, S.; Barbosa, O.; Zidoune, M.N.; Fernandez-Lafuente, R. Immobilization/Stabilization of Ficin Extract on Glutaraldehyde-Activated Agarose Beads. Variables That Control the Final Stability and Activity in Protein Hydrolyses. Catalysts 2018, 8, 149. [CrossRef]

5. Hitaishi, V.P.; Clement, R.; Bourassin, N.; Baaden, M.; De Poulpiquet, A.; Sacquin-Mora, S.; Ciaccafava, A.; Lojou, E. Controlling Redox Enzyme Orientation at Planar Electrodes. Catalysts 2018, 8, 192. [CrossRef] 